\title{
DELTAGELSENS KUNST?
}

PARTICIPATORY ART? I Within recent years, art and urbanism have gradually moved closer to each other and come together around socially engaged, dialogical projects. Participation and the creation of urban publics are topics that often concern artists as well as urban planners and activists. Based on a record of this recent conjunction between art and urbanism, the article examines practices, fractures, and conflicts in the aftermath of the social turn. With a point of departure in the coalescing public programme of the Istanbul Biennial and Occupy Gezi at Taksim Square in 2013, the article questions the art of participation. What type of public is created in the participative art? And is an artistic social turn towards the city even possible beyond the art institution? The article concludes that precisely in the conflict between the two different rationales of art and urbanism a participatory, urban public can emerge; a public, however, which lie beyond the intention and rationales of the individual actor.

KEYWORDS I art in public; urban publics; curating; the social turn; public programme; urban activism; urbanism; art institutions

Deltagelse er blevet et buzzword i de senere år. Uanset om vi taler om offentligt støttede kulturaktiviteter eller byudvikling og design, er der stadig stigende opmærksomhed på at forankre disse i civilsamfundet. Deltagelse synes at være nøglen til dette og er således blevet omdrejningspunkt i en række nye diskurser, der både afspejler og stimulerer en række nye praksisser. Men hvad motiverer disse processer, og hvad genereres der igennem dem? Denne artikel optegner, hvad vi ser som en performativ drejning inden for samtidskunsten og urbanismen, og undersøger de problematikker, der rejser sig, når kunsten træder ind på den urbane scene. Her synes det relevant at stille spørgsmål som: Hvad er og hvad genererer offentlighed? Hvad er deltagelse? Hvad er bevæggrundene for inddragelse og på hvis præmisser? Hvem skal og kan inddrages; Hvem ekskluderes? Hvad betyder det, om deltagelse opstår spontant eller i en ramme, struktureret af en afsender? Disse spørgsmål vil besvares forskelligt af kunstnere, kulturinstitutioner, byplanlæggere og urbane aktivister. Derfor lægger artiklen ud med at kortlægge nogle hovedtræk i den performative vending inden for hhv. kunsten, kulturinstitutionen, byplanlægningen og urbanismen.

Inden for alle felter kan vi skelne mellem forskellige diskurser. På den ene side en demokratisk og politisk motiveret idé om inddragelse som empowerment, hvor 
social produktion af rum anses for at skabe et socialt inkluderende (by)rum med et fungerende civilsamfund ${ }^{\mathrm{r}}$ og måske lige frem emancipation af subjektet. På den anden side en inddragelsesdiskurs med et oplevelsesøkonomisk og byudviklingssigte, hvor deltagelse er knyttet til målet om at nå ud til et bredere publikum i form af forbrugere. ${ }^{2}$ Endvidere er deltagelse motiveret af såvel legitimering af offentlig støtte som stigende krav om egenfinansiering af offentlige institutioner. Men i hvor høj grad bliver diskursen om deltagelse og inddragelse til et strategisk greb eller en token for egentlig demokratisk proces, og hvordan harmonerer idealerne med den konkrete praksis?

Istanbul Biennale i efteråret 20I3 er et eksempel på en sådan konflikt mellem planlagt og spontan deltagelse. Her havde kuratorerne planlagt at italesætte problemstillinger omkring manglende ytringsfrihed, kommercialisering og gentrificering af byrummet. I mellemtiden, parallelt med planlægning af biennalen, eskalerede en række konflikter i byen, og en række mere eller mindre koordinerede demonstrationer, besættelser og performance aktioner fandt sted i og omkring Taksim-pladsen - en plads, der for aktivisterne repræsenterer det moderne Istanbul og en demokratisk offentlighed. Selvom biennalen havde til sigte at stille sig pà borgernes og aktivisternes side, endte de på kollisionskurs, og en stor del af det aktivitetsprogram bestående af performances og seminarer, der løb forud for og parallelt med udstillingen, måtte aflyses.

Med afsæt i denne case diskuteres nogle af de iboende konflikter og forskelle mellem den måde, hvorpå de kulturelle institutioner og kunstnerisk-æstetiske praksisser fungerer, og den kollektive deltagelsesform, som den urbane aktivisme anvender i sit forsøg på at generhverve sig retten til byen og det offentlige rum.

\section{Den sociale vending inden for billedkunst og teater}

I samtidskunsten har man inden for de seneste årtier set en social vending, der $\mathrm{i}$ flere projekter indbefatter en deltagelsesdiskurs, som er rettet mod offentlighed og byrum. På forskellig vis inddrager de sociale værker sociale relationer og praksisser som en integreret del af værket. Det sker f.eks. ved at gøre selve det sociale samvær til omdrejningspunkt som i Rirkrit Tiravanijas thai-måltider, ved at arbejde med den eksisterende sociale og urbane problemstillinger som Kenneth Balfelts projekter i byrummet, eller gennem diskursive og strukturelt engagerede projekter af institutionskritisk eller selv-institutionaliserende art som f.eks. Københavns Fri Universitet ved Jakob Jakobsen og Henriette Heise. Socialt orienterede praksisser blomstrede $i$ løbet af I990'erne og oo'erne i en mangfoldighed af strømninger og benævnelser som 'new genre public art' (Lacy), 'relationel æstetik' (Bourriaud), 'samtaleværker' (Kester), 'social intervention', 'performative praksisser', '2. generation institutionel kritik', 'post-studio practices' og 'post-autonomous practices' mv. Kendetegnende

I Se f.eks. Lilliendahl Larsen eller Lefebvre.

2 For en diskussion og kritik af det oplevelsesøkonomiske, se f.eks. Dorte Skot-Hansen og Bang Larsen. for disse praksisser er, at æstetik som et formspørgsmål træder i baggrunden til fordel for en virkningsæstetik, hvor affekt, effekt og social forandring står i centrum (Thompson). Ret centralt i disse socialt orienterede praksisser står inddragelse og publikumsdeltagelse, ligesom værkerne eller projekterne ofte anvender viden og teknikker fra andre fagfelter og generelt indskriver sig i en social sammenhæng, der adskiller sig fra den klassiske udstilling.

Inden for teatret kan man i samme periode se lignende træk i det postdramatiske teater (Lehmann 1999). Termen 'det postdramatiske' teater dækker en lang række af ikke-repræsentationelle teaterformer primært udviklet efter 1960. De har det til fælles, at den dramatiske tekst ikke står i centrum. Shannon Jackson har opsummeret det som et teater, der modsætter sig katharsis, som dekonstruerer den kanoniske tekst og som ikke mindst tilnærmer sig det politiske fra et postBrectiansk udgangspunkt, der gentænker kulturindustriens signatur snarere end at afvise den (Jackson 2).

Instruktører som Heiner Müller og Robert Wilson er centrale figurer, ligesom grupper som The Living Theatre og siden Gob Squat, The Wooster Group, Forced Entertainment, Rimini Protokoll og danske Hotel Proforma er indflydelsesrige repræsentanter for det. Et eksempel er Rimini Protokolls Call Cutta in a Box, hvor publikum én ad gangen bliver inviteret ind i et lille kontor, og der via telefon og computer møder en skuespiller angiveligt placeret i et call-centre i Calcutta. Man indbydes til en dialog, der strækker sig fra global økonomi, arbejdsbetingelser i call-centeret, illusionen om at de ringer fra et sted nær dig, til mere private - endda intime - aspekter af livet, godt hjulpet på vej af forskellige tekniske virkemidler.

Den sociale vending er et overordnet begreb, der opsamler sociale eller socialt orienterede praksisser i samtidskunst og teater. Det sociale indebærer at skabe social og strukturel forandring til praksisser, hvor det sociale betragtes som et kunstnerisk medium, en æstetisk undersøgelse af tid, kollektivitet, handlinger og performance. Også inden for kuratering kan man genfinde en social drejning, der er karakteriseret ved samme forståelse af det sociale som mål med et evaluerbart output eller en æstetisk, social proces med et åbent mål.

Den sociale vending $\mathrm{i}$ både kunst og kuratering rokker således ved æstetikhistoriens forestillinger om kunstens autonomi samt værkets udstrækning og grænse. I hvilken grad eksisterer kunsten i sit eget æstetiske domæne? Og i hvilken grad skal den række ud efter, gribe ind i eller ligefrem opløses i samfundet? Inden for avantgardekunsten - især inden for billedkunsten og teateret - har der siden det tyvende århundredes begyndelse været utallige forsøg på at gentænke relationen mellem, på den ene side, den æstetiske udfoldelse og autonomi, og på den anden side, det sociale liv. Fra en forståelse af at kunsten alene er er et anliggende, der berører vores kropslige og sanselige perception, til at den også relaterer sig til verden og er en del af dennes materialitet; fra at være en kulturel institution i samfundet til at være en agent for forandring af samfundet og hverdagslivet.

Den sociale vending hænger også sammen med, at kunsten bliver mere performativ. Eller rettere, samtidskunsten kommer til at udfolde sig i et felt mellem 
det klassiske, modernistiske værkbegreb og performance. Derfor ser vi den sociale vending også som en performancevending, hvor det udvidede værkbegreb bevæger sig mod et grænseløst værk, der enten absorberes af omverdenen eller manifesterer sig som en handling eller proces i verden. Denne gradvise opløsning af grænsen mellem værk og samfund får naturligvis betydning for, hvilke positioner betragteren eller publikum har og for kunstens relative autonomi. Med den modernistiske kunst blev adskillelsen mellem værk og omverden konceptuelt opretholdt. Også selvom skulpturen fratages sin sokkel og står på gaden side om side med de forbipasserende. Trods denne karakter som objekter i verden fungerer de modernistiske værker autonomt, de er selvberoende, har en egen realitet og en iboende betydning, der peger ud over deres situerethed og relation til omverden. I den sociale vending bevæger billedkunsten sig mod teaterets forhold. I teater og performance er dobbeltforholdet af et symbolsk, referentielt niveau og en fysisk realitet mere udtalt, idet man ofte ikke kan adskille værket fra de tekniske og sociale rammer; skuespillerens krop, lyssætning, publikumsreaktioner mv. er medskabende faktorer. Med den sociale vending bliver dette mere kompliceret - og illusionen om klare grænser mellem værk og verden bliver opløst. Her kan kunstens formmæssige dimensioner også omfatte en måde at relatere til publikum på, hvor f.eks. inter-subjektive udvekslinger kan være en del af selve værkets materiale. Det bliver med andre ord svært at trække en linje for, hvor kunsten slutter, og hvor resten af verden, med dens socialitet, hverdagsæstetik og udvekslingsprocesser, begynder.

Den sociale vending i kunsten er altså også en performativ vending, hvor værket åbner sig mod ydre omstændigheder, mod virkning frem for væren, og dermed også åbner sig for det opstående, emergente i f.eks. hverdagslivet eller i den urbane kontekst. Virkning skal dog ikke nødvendigvis forstås som målrationale, men kan også betragtes som resultat af en åben proces. Inddragelse af publikum kan ligeledes betragtes på flere planer som i teateret, hvor publikums kropslige nærvær og affektive reaktioner er bidragende, eller som en overdragelse af noget af auteur-rollen, en større eller mindre afgivelse af kunstnerisk kontrol over proces og resultat. I begge tilfælde ser vi en ændret forståelse af publikums rolle efter den sociale vending, et grundlæggende opgør med forestillingen om en passiv betragter (Rancière The Emancipated Spectator), og som bevæger sig hinsides diskussionen om forfatterens død. Kunsten efter den sociale vending placerer sig altså refleksivt $\mathrm{i}$ et felt udspændt mellem det autonome, selvdefinerende og det heteronome, afhængige, og mellem det intenderede og det emergente, mellem kontrol og kontrolafgivelse.

\section{Sammenblandede diskurser?}

I Bishops analyse af deltagelseskunsten handler den sociale drejning dog ikke alene om en kunstnerisk tendens i tiden, men også om en politisk diskurs hos britiske New Labour og en række andre europæiske politikere, som anvender deltagelsesretorikken til at retfærdiggøre kunststøtte. Social inklusion gennem deltagelse i kulturen styrker den sammenhængskraft, som det neoliberale arbejdsmarked ikke formår at skabe. Men hvor deltagelse, fællesskab og kreativitet i I960’ernes modkultur handlede om subversive og antiautoritære kræfter, har disse begreber ændret betydning og er blevet buzzwords for 'the new economy' i løbet af I990'erne og frem til krisen i 2008, pointerer Bishop (I3-I5). Den kreative sektor skulle være en økonomisk drivkraft, mens kulturfeltet skulle være bedre til at udnytte sit markedspotentiale. Ligeledes bliver kunstnerens måde at arbejde på gjort til rollemodel, 'the no-collar workforce' (Ross), som er en arbejdsstyrke, der har en arbejdsmentalitet baseret på fleksibilitet og parathed og som er villige til at ofre ordentlig betaling og sikkerhed i ansættelsen for relativ frihed, selvrealisering og symbolske goder. Sat på spidsen kan deltagelse og 'enhver en kreativ medarbejderparadigmet' afrette borgerne til at underkaste sig autoriteter og samtidig forberede dem til overtage al risiko i en skrumpende velfærdsstat. Bishops pointe er, at denne sammensmeltning af diskurser også sker fra kunstnernes og kuratorernes side. Det vil sige, at kunstprojekterne evalueres i et etisk lys frem for i et æstetisk. De vurderes på om de reelt inddrager borgerne, altså på karakteren af de relationer, der skabes. Hermed bliver det uklart, mener hun, hvad det æstetisk-kunstneriske bidrag til processen reelt er, hvorved kunstnerisk kvalitet glider ud til fordel for en ren nytteværdi eller etisk vurdering: etisk godt = god kunst.

Denne pointe kan diskuteres, men for denne artikels vedkommende er sammenblandingen af diskurser relevant, idet netop nytteværdien og anvendelsesperspektivet fremhæves, når kunsten møder urbanismen. I disse sammenhænge bliver æstetiske virkemidler til redskaber, hvor projekterne typisk bliver vurderet på deres kapacitet til at igangsætte social forandring, opfordre til borgerens deltagelse eller være en ny, mere sexet form for borgerinddragelse. I praksis kommer kunstprojekterne ofte til at eksistere et sted midtimellem, hvor de hverken opleves som effektive eller kunstneriske interessante og nyskabende. Tilmed kan disse projekter dække over en manglende reel politisk inddragelse. Dermed ikke sagt, at sådanne projekter ikke kan lykkes eller være interessante, men blot at der er behov for udvikling af en mere nuanceret diskurs og måde at evaluere projekterne på.

\section{Deltagelsesdiskursen i kulturinstitutionen}

Bishops beskrivelse af den neoliberale diskurs i Storbritannien kan vi også genkende $i$ en dansk kontekst i forhold til, hvordan kulturpolitik redefineres i takt med velfærdsstatens afvikling. En sammensmeltning af diskurserne gør sig især gældende, hvor kunst og kreativitet gradvist er blevet synonymer, og hvor man i stigende grad søger at udvide beskuerbegrebet til et deltagerbegreb. Det er således blevet nærmest obligatorisk for offentlige kulturinstitutioner at have et 'outreach'- eller eventprogram, der søger at inddrage såkaldt nye publikumsgrupper eller inddrage publikum på nye måder. I en dansk sammenhæng kan man pege på SMK Fridays på Statens Museum for Kunst, Outreach på Kunsthallen Nikolaj og Aros 27 Lounge. Denne strategi kan indlæses i en bredere tendens mod oplevelsesøkonomien, hvor f.eks. Olafur Eliassons Yor Rainbow Panorama på ARoS symptomatisk integrerer 
city-branding og kunst, idet regnbuen konceptuelt såvel som æstetisk-receptivt iscenesætter Aarhus som en farvestrålende og kreativ by. Forud for og parallelt med dette har en række eksperimentelle kunstinstitutioner taget arven op fra den institutionelle kritik og søgt at få institutionen ud af kunstboblen. Her foregår og foregik gentækningen af institutionen dog i forhold til rationaler knyttet til den tidslige programmering, diskursive rammesætninger, den sociale og faglige rækkevidde, ved at forbinde dem med andre miljøer, typisk forsknings- og uddannelsesmiljøer og andre kritiske og debatterende kulturmiljøer, samt ved at relatere dem til lokale socialt stigmatiserede grupper. Eksempler på sådanne institutioner var Rooseum i Malmö under Charles Esche og Kunstverein München under Maria Lind, der er Casco og BAK i Utrecht, The Showroom i London under Emily Pethick, og Tranzit netværket i bl.a. Budapest og Prag. ${ }^{3}$

Selvom der både i diskurs og praksis er overlap mellem de politisk topstyrede og institutionelt selvdefinerede mål med deltagelse og åbning af institutionerne, er der både ideologiske og metodiske forskelle. Hvad motiverer disse tiltag? Bliver disse institutioner sociale kontrol organer eller cover-ups for mislykkede social politik? Hvilket f.eks. er en udbredt kritik af Britisk New Labours politik (Harvie). Eller er det næring til civilsamfundet, til den uafhængige tænkning og udveksling af ind- og udtryk? Og hvornår bliver en generel samfundsmæssig forpligtelse i de offentlige eller offentligt støttede kunstinstitutioner til politisk diktat og manglende armslængde? Der hvor ambitionen om institutionel deltagelse lykkedes bedst, er i de tilfælde, hvor det gav anledning til, at institutionerne dels har arbejdet med en restrukturering, der giver en bedre forankring i lokalmiljøet (f.eks. The Showroom, London), og dels involverer kunstnere, hvis praksis i forvejen er investeret i sociale miljøer. Der er dog en udpræget fare for en managementkultur, der handler om box-ticking og besøgstal, uden at man kan diskutere de kvalitative aspekter af borgernes møde med kunsten eller institutionens rolle i samfundet som sådan.

\section{Den sociale vending $i$ byplanlagning og bydesign}

Inden for byplanlægningen ser man ligeledes ønsket om at inddrage borgerne, ikke blot i beslutningsprocesserne, men også i designpraksissen. Her spiller kunsten ofte en rolle, idet den tilskrives en evne til at skabe engagerende, sanselige og/eller diskursive rum, der på én gang kan virke autonomt i forhold til de økonomiske og samfundsmæssige interesser og samtidig understøtte planlægningens målrationaler om en demokratisk og brugerdreven proces. Vi ser således eksempler på, at kunstnere og kuratorer inddrages i omdannelsesprocesser til at bygge modne områder (f.eks. Køge Havn), eller at man gennem kunsten ønsker at give en fornemmelse af direkte borgerinddragelse (f.eks. Superkilen i København). Vi ser samtidig en lang række selvorganiserede initiativer, der strækker sig fra de mere konsensussøgende projekter med fokus på bæredygtighed, grønne initiativer og

Disse institutionelle praksisser kaldes ofte New Institutionalism. Se Ekeberg og Möntmann. inkluderende samvær (som f.eks. urban gardening og fællesspisning i Prags Have) til de mere antagonistiske og politisk ladede projekter som Folkets Park på Nørrebro, og tidligere Byggeren, var det.

Nye metoder for planlægningen er opstået i kølvandet på, at nye tværdisciplinære samarbejder mellem kunstnere, arkitekter, borgere og kommunens planlægning er opstået. Hvor det tidligere var arkitekten, der forestod byplanlægningen, er det i dag en disciplin, der også varetages af kommunikations-, kultur og økonomimedarbejdere. Det har også ændret kunstens rolle. Hvor kunst i det offentlige rum $i$ en dansk kontekst tidligere havde en funktion som udsmykning eller som et element $\mathrm{i}$ den almene dannelse, er kunst $\mathrm{i}$ det offentlige rum $\mathrm{i}$ løbet af de sidste IO-I5 år i stigende grad blevet en integreret del af byudviklingen og bruges ofte som procesredskab. Den danske kunstnergruppe Superflex taler specifikt om "tools" som et centralt element i deres praksis, og det bruges i forbindelse med deres brugerinddragende processer på blandt andet Superkilen på Nørrebro, København. Ligeledes har kunstneren Kenneth Balfelt i sin Genhusning af oldrikkere på Enghave Plads været interesseret $i$ at adressere og engagere pladsens såkaldte 'superbrugere' - øldrikkerne på pladsen. Køge har i konkurrencen med andre byer fokuseret på kulturel byudvikling (Jørgensen), og anvender den sociale og brugerinvolverende kunst i strategisk byudvikling på havneområdet. Det har resulteret i en række udstillinger og tiltag i overgangsfasen fra industrihavn til beboelsesområde. Både anerkendte gadekunstnere og billedkunstnere, der arbejder med socialt forandrende kunstgreb, inviteres således til at bruge den urbane offentlighed som et eksperimentarium, idet man qua det planlægningsmæssige rationale ønsker en særlig effekt af kunsten. Projekter som Walk This Way og Urban Play i Køge er eksempler på, hvor den inddragende og relationelle kunst iscenesættes som en del af byudviklingens rationaler (Fabian \& Samson).

Der er således i dansk såvel som i europæisk byplanlægning generelt kommet et øget fokus på kunstens sociale- og brugerinvolverende egenskaber, der af planlæggere og kunstnere ses som en mulighed for at lægge bydesign og beslutninger ud blandt borgerne, og derved gøre byplanlægningen mere demokratisk og bottom-up styret. Samtidig ligger der i denne anvendelsesorientering af kunsten en performativ drejning, der tilskriver kunsten agens og virkning. Hvor det performative kunstværk (Jalving) tilskrives en kapacitet til at handle på sin beskuer, kan man sige, at den brugerinvolverende kunst har en kapacitet til at virke forandrende på den urbane offentlighed, f.eks. ved at være socialt inkluderende eller rejse debat om de måder, hvorpå byer udvikles og formes i dag. Midlertidighed og en åben, processuel transformation spiller således en væsentlig rolle, når kunsten bruges som katalysator i byomdannelse. (Se f.eks. Oswalt, Mitzelwitz, Obermeyer).

Alliancen mellem kunst og urbanisme finder også sted som aktivistiske modstandsformer i de hastigt voksende globale storbyer som Istanbul og Rio de Janeiro, hvor social udstødelse og gentrificering er langt mere presserende end i en nordeuropæisk kontekst. Modstanden mod den socialt ulige by og stratificeringen af byens mangfoldighed har globalt affødt aktivistiske sociale bevægelser, der finder 
sammen i æstetiske fællesskaber, som typisk arbejder med at skabe kollektive mikro-utopier, og med inspiration i kunstens autonomi skaber alternative byrum og sociale fællesskaber. En sådan "kreativ aktivisme" (Harrebye) adskiller sig fra den politiske kunst ved typisk at praktisere den forandring, de ønsker implementeret. Ikke desto mindre synes der også at være en konflikt indlejret $\mathrm{i}$ alliancen mellem urbanismen og den socialt orienterede kunst: Diskursen i den sociale kunst hviler typisk på et socialt inkluderende rationale, at de udformede byrum skal være til gavn for alle. Her følger såvel kunsten som aktivismen et af urbanismens stærkeste dicta om "byer for alle" og "retten til byen", som først blev formuleret af Lefebvre i hans Le Droit à la ville fra 1968, og som senere har udgjort en central del af geografen David Harveys kritik af den kapitaldrevne byudvikling (Harvey, "The Right to the City") (Harvey, Rebel Cities).

Ikke desto mindre har de seneste års udvikling vist, at netop kunsten og det brugergenererede indhold, hvor borgeren via kunsten inviteres til at medudvikle byrummet også bruges strategisk til netop at lancere og legitimere den kapitaldrevne byudvikling (Fabian \& Samson). Kunsten bruges her som et strategisk værktøj, der kan åbne op for borgerens engagement - en stratificering af kunsten såvel som af borgerens deltagelsesengagement, der ofte står i direkte modsætning til udgangspunktet, nemlig kunstens relative autonomi, og hvor værdier som inklusion, åbenhed og værket som en social proces netop udfoldes som kritik af samfundets og den kapital- og konkurrencedrevne byudviklings målrationaler. Når den sociale og deltagende kunst således bruges som en katalysator for byudvikling med borgeren som en inviteret kreativt skabende aktør, synes det derfor relevant at spørge ind til, på hvilke og på hvis præmisser denne deltagelse finder sted?

Samtidig kan kunstnernes rationaler for at indgå i disse instrumentelle samfundsprocesser også belyses. I projekter som f.eks. Balfelts Genhusning af øldrikkere på Enghave Plads i København eller Kerstin Bergendals Park Lek (Parkleg) i Hallonbergen, Stockholm, er social forandring ikke et abstrakt mål, men derimod en serie af helt konkrete handlinger, der skaber nye strukturer for borgerinddragelse. Sådanne projekter lægger sig op ad ideerne om alles ret til byen, men understøtter samtidig forskellige aspekter af kunstnerens personlige praksis og metodologi. Eksempelvis Balfelts interesse for det offentlige rum og hans metodiske tilgang til brugerinddragelse i problemløsning og design. Herved opretholdes en kunstnersignatur gennem konkrete metoder, selvom værket som sådan er opløst, eller i hvert fald distribueret på flere aktører. Inddragelsens karakter og omfang vil altid være op til kunstnere. Borgeren bliver med andre ord i bedste fald garant for sit eget og kunstens skabende samfundsengagement, men i værste fald et strategisk redskab for kunstnersignaturens succes og offentlige anseelse.

De aktivistiske bevægelser har, i lighed med den urbane kunst og visse deltagelsesorienterede kunstinstitutioner, et kritisk og demokratisk sigte, der ønsker at bryde med hierarkier og eksisterende magtrelationer. Selvom aktivisterne arbejder kollektivt og ud fra en forestilling om delt indhold, kan man med rette påpege, at de i deres manifestationer nærmer sig performancekunstens værkæstetik, der er inspireret af f.eks. avantgardens happenings med dens intervention og sammenblanding af det symbolske og det reelle, af installationskunstens sammensatte rum og performanceteatrets rumlige iscenesættelser. Også protestformen er ikke længere kun verbal, men har antaget eventkarakter, hvor æstetiske, visuelle og rumlige taktikker tages i brug (Feigenbaum, Frenzel \& McCurdy, Harrebye). På trods af de åbenlyse forskelle mellem aktivisme og den urbane kunst, er der flere eksempler på deres konvergens.

Under dOCUMENTA I3 i Kassel inviterede kurator Carolyn Christov-Bakargiev eksempelvis en Occupy Wall Street camp ind som en levende kunstperformance foran Fridericianum - Dokumentas hovedbygning og symbol på den institutionaliserede og rammesatte kunst. Ved at lade den spraglede teltlejr spejle af en minimalistisk hvid teltlejr, der konnoterede kunstgalleriets hvide kube, forsøgte Bakargiev at etablere en gensidig forståelse af kunstens kritiske rationaler og aktivismens ditto. Men lighederne forefindes ikke kun i det kuratoriske greb, men også i de spontane og æstetiske medier og modstandsformer, som henholdsvis byaktivismen og kunstaktivismen udtrykker sig gennem.

Der hvor den sociale drejning i kunsten, inden for institutionerne, i byplanlægningen og i aktivismen mødes, er i ønsket om at undslippe de kulturelle hierarkier og økonomiske rationaler for forandring. Hvad enten deltagelse af en bredere offentlighed indebærer inklusion af undertrykte eller oversete borgere, af den ikke allerede kulturelt indviede kulturbruger eller handler om borgerens ret til byrummet, kan deltagelsens kunst anskues som et alternativ til modernismens autoriteter og topstyrede kultur. At disse autoriteter har forskellige ansigter - f.eks. kunstinstitutionen, staten, den politiske diskurs, kapitalismen - gør deltagelsen til et modsætningsfyldt fænomen, hvor institutionskritikken rettes mod forskellige fjender, og hvor idealet om deltagelse i bedste fald hviler på et uopnåeligt ideal om demokrati og lighed, på falske forestillinger om konsensus og dialog, eller i værste fald opdyrkning af nye former for forbrug.

Med Istanbul Biennalen 2013 vil vi illustrere det både modsætnings- og konfliktfyldte $i$ at arbejde med deltagelsens kunst, og samtidig give nogle bud på, hvorfor den sociale vending og ambitionen om deltagelse af den urbane offentlighed alligevel er nødvendig at italesætte og arbejde med.

Mom. Am I a barbarian? Kampen om Istanbuls offentlige rum Istanbul Biennalen i 2013 er et godt eksempel på, hvordan forskellige diskurser omkring kunst, deltagelse og offentlighed kolliderer. Biennalens kuratoriske rammesætning var ideen om den offentlige sfære som et politisk forum. Denne ramme skulle give afsæt til nye ideer og praksisser, som kunne udfordre samtidige former for demokrati, eksisterende modeller for spatio$ø$ konomisk politik, nedarvede forestillinger om civilisation og barbari, og 
fremfor alt udfolde samtidskunstens rolle som en agent, der både skaber og afvikler, hvad der forstås som offentligt. 4

Allerede i januar 20I3, et halvt år før udstillingsåbningen, lancerede kurator Fulya Erdemci med sit kuratoriske team det offentlige program, der både skulle italesætte problemstillinger omkring manglende ytringsfrihed og den omfattende gentrificering af byen. ${ }^{5}$ Programmet skulle foregå ved og i de omdiskuterede byrum, såsom Taksim-Pladsen og Gezi Park. Hensigten med programmet var ikke blot at tematisere diskursen omkring den offentlige sfære som sted for politisk forandring, men netop at undersøge dens potentiale ved så at sige at stille sig på borgernes og demonstranternes side. Biennalens kunstneriske leder Erdemci og kurator for Public Programme Andrea Phillips måtte imidlertid konstatere, at de offentlige rum, som skulle udgøre den formelle scene for debat, var blevet privatiseret eller overtaget af bystyret for at indgå $\mathrm{i}$ kommercialiseringen af byrummet, heriblandt det ikoniske Ataturk Kulturcenter på Taksim-pladsen, som for mange borgere i Istanbul (herunder aktivisterne) står som symbol på det moderne Tyrkiets kulturelle kvaliteter både i kraft af den særlige arkitektur fra I960'erne og de kulturinstitutioner, som bygningen rummede frem til 2008. Det ledte til, at de indledende arrangementer helt konkret blev overtaget af aktivister. Kuratorerne svarede i første omgang igen med at flytte arrangementer til mere beskyttede steder som universitetet, men måtte til slut aflyse en stor del af programmet. ${ }^{6}$ Erdemci og Phillips så sig således nødsaget til at trække det offentlige program tilbage for ikke at acceptere eller blive identificeret med Istanbuls eskalerende gentrificering (Golonu).

Biennalens offentlige program kan ses som kunstverdenens (kuratorernes, kunstnernes) ønske om at italesætte bypolitiske og byrumlige problematikker. I Istanbul har denne diskurs eksisteret uafhængigt af kunstinstitutionen længe inden både biennalen og Occupy Gezi fandt sted i 20I3. Den er vokset frem i takt med, at byen har vokset sig til en global storby. Den komplekse byudvikling har indbefattet gentrificering og oprydning, med udrensning af den urbane mangfoldighed til følge - både arkitektonisk, kulturelt og socialt. En udvikling som forfatteren Orhan Pamuk levende beskriver i sin erindringsbog Istanbul (på dansk 2007). Taksim-pladsen er blot ét ud af mange eksempler på en monopolisering og kommercialisering af byrummet. Den offentlige debat omkring byrummet har i lang tid ulmet i Istanbul, hvor forskellige aktivistiske og kulturelle aktører har brugt kunst, kultur og design som en modstand mod den konservative og kapitaldrevne omdannelse af byen, der sker i disse år. Dokumentarfilmen Ekumenopolis (Imre Azem 20II) følger disse

I3th Istanbul Biennial Conceptual Framework, http://r3b.iksv.org/en\#_ednı

I modsetning til hvad der ofte er tilfsldet ved internationale biennaler, kender Erdemci Istanbul aldeles godt, idet hun vender tilbage til sin hjemby efter 4 år som leder af SKOR (Fonden for kunst i det offentlige rum), Amsterdam.

6 Begivenhederne er redegjort for i en del offentlige presentationer af både Fulya Erdemci og Andrea Phillips, herunder seminaret, Art Caught in the Crossfire i København d. 21/3/14 urbane bevægelser og opsummerer deres rationaler som en reaktion på den globale og kapitaldrevne byudvikling i overensstemmelse med tankerne fra retten til byen-bevægelsen og den kritiske geografi (Lefebvre, Harvey).

I det lys spiller kunstinstitutionerne og Istanbuls privatdrevne gallerier en væsentlig rolle, idet de ifølge mange af de urbane aktivister udgør en del af den globale, kapitaldrevne udvikling af Istanbul. Gallerier som Milk, Salt (som fast samarbejder med biennalen) og ikke mindst det privatsponserede museum Istanbul Modern (som overtog bygningen fra den 8 . biennale 2003) tegner således en international profil med ambitioner om at operere på det globale kunstmarked og $i$ et dertilhørende kunstsystem. Occupy Gezi kan i den forstand ses som kulminationen på flere års ulmende kamp om retten til byen, hvori kunstinstitutionerne og gallerierne har spillet en tvetydig rolle, idet de på den ene side er sponseret a private investorer (typisk pengeinstitutter) med åbenlyse aktier i Istanbul som global kunstmetropol og dermed også i kulturens gunstige effekt på værdien af f.eks. fast ejendom. På den anden side huser kunstinstitutionerne kunstnere og inviterer internationalt virkende kuratorer og akademikere, der forholder sig kritisk til selv samme udvikling.

For aktivisterne kan biennalen derfor ikke ses som et led i kampen mod denne byudvikling, når institutionen netop er en del af problemet. Det resulterede konkret $i$, at aktivisterne tog kraftigt afstand fra biennalens program i det offentlige rum. Omstændighederne blev mere komplekse, idet en intensiveringen af protester omkring Gezi Park i maj 20I3 betød, at aktivister og kulturelle aktører, der ikke var associerede med biennalen indtog de rum, som biennalen havde planlagt at bruge til deres kunstinterventioner. Hvad der skulle have været iværksat som en del af biennalen, blev således foregrebet og eksekveret af aktivisterne under Occupy Gezi i maj og juni. Hvor der var overlap i aktivisternes og kuratorens ønske om at bekæmpe undertrykkelse af ytringsfriheden og dæmme op for hyper-kommercialiseringen af byudviklingen, var der også tydelige forskelle. Hvor det var et praktisk anliggende hos aktivisterne, der omhandlede retten til byen, var det et diskursivt anliggende hos kuratorerne. Der var især en radikal kulturforskel, når det kom til organisationsform og idéen om deltagelse. Mens biennalens program var deltagelsesorienteret gennem delegering, invitation til at deltage i diskussionen, blandt andet gennem en workshop på Hotel Marmara, der kritisk italesatte det globale kapitaldrevne kunstmarked, var aktivisternes performanceformater typisk udviklet kollektivt of fandt sted spontant i det offentlige rum uden nogen individuel afsender. Nogle af aktionerne var deciderede modtræk til biennalens program for det offentlige rum. Eksempelvis afbrød aktivisterne den kritiske workshop på Hotel Marmara Taksim.

Andre performances i biennaleprogrammet rettede en kritik mod Tyrkiets manglende ytringsfrihed og insisterede på retten til både at ytre sig og bruge det offentlige rum. Hvor biennalens planlagte kunstperformances havde en mere konceptuel karaktér og indgik i et program, der også omfattede mere akademiske, diskursive italesættelser af retten til at ytre sig i det offentlige rum, havde flere af aktivisternes ytringer et kunstnerisk og skabende islæt, hvor performative, visuelle 
og kropslige taktikker blev taget i brug. Disse aktioner fokuserede mindre på verbale og diskursive italesættelser af retten til byen og mere på direkte handlinger, der indtog byrummet og således skabte en momentan offentlighed.

Performanceprotesten Standing Man - på tyrkisk Duran Adam - er et eksempel på, at byaktivismen gennem sine spontant organiserede protestformer tilegner sig et performanceformat, der spreder sig og integreres i den sociale kontekst. Standing Man bestod af en performancekunstner, der i protest mod bystyrets og regeringens magtudøvelse og vold mod demonstranterne stillede sig op foran magtens monumenter og blev tavst stående. Denne enkle performance-gestus spredte sig hurtigt via sociale og visuelle medier til en kollektiv handling, hvor folk ikke bare Istanbul, men også i resten af Tyrkiet, og sågar i Brasilien, stillede sig op med deres krop som protest. Denne performanceudgave af sit-in protesten italesatte således ikke blot borgerens ret til at ytre sig i det offentlige rum, men resulterede også i en fysisk og kropslig deltagelse af mange forskellige sociale og kulturelle grupper. Samtidig manifesterede og materialiserede performancen det urbane diktum om retten til byen, idet folket reelt generobrede pladsen med kroppen som medium.

Et andet eksempel er den omfangsrige gadekunst og guerilla gardening, der fandt sted i Gezi Park. Den fungerede på én gang som rumlig og visuel kommunikation - at her ønsker vi et andet grønt og demokratisk rum end regimets grå og kommercielle beton - og materialiserede samtidig en åben og inkluderende tilblivelse, der kom til syne i de kollektive, spontane og ofte humoristiske udtryk, som aktivisterne skabte (se f.eks. Altay). Som aktivisten og urbanisten Yasar Adanali påpeger, var Occupy Gezi en mangfoldighed af udtryk eller en "multitude" (Hardt \& Negri), idet aktionsformerne både rummede sociale, kulturelle og politiske forskelligheder, der dog momentant sameksisterede. Som aktivisten og urbanisten Adanali påpeger, så tillod gezi-protesterne forskelligartede interesser at udtrykke sig med deres specifikke agenda, men udgjorde samtidig det, han betegner "a unified multitude" (Adanali)

I en sådan samlet multitude identificerer han et opgør med den globaliserede ensretning, der bl.a. findes i kunstinstitutionen og biennalen. Man kan påpege, at en sådan heterogen sameksistens af socialiteter delvist var ekskluderet fra Istanbul Biennalens offentlige program, idet afsenderne arbejdede inden for kunstinstitutionens rammer - med de begrænsninger det måtte have. I den forstand spiller de supportstrukturer, f.eks. sponsorer og biennalen som en international aktør en væsentlig rolle, hvorimod de aktivistiske tiltag opstod spontant og måske netop qua det utilsigtede formåede at inkludere forskelligartede og endda modstridende politiske anskuelser. Men de modstridende interesser og deres sameksistens gør sig i princippet også gældende for biennalen. Udefra, herunder set fra aktivisternes perspektiv, fremstår biennalen som institution og som en irammesat begivenhed i 2013. Ikke desto mindre er der flere agendaer i spil. De enkelte kunstnere har deres personlige og politiske motiver for at deltage, kuratorerne har deres faglige og politiske visioner, og institutionen har sine. Institutionen vil nødvendigvis søge at sikre sin langsigtede overlevelse politisk og økonomisk. Oven i dette må man huske, at kunsten ofte spiller med komplekse, tvetydige udsagn, der åbner for nye spørgsmål frem for at besvare eksisterende. Når vi taler om deltagelsens kunst, er der med andre ord også inden for biennalen tale om en pluralitet eller en multitude af rationaler.

\section{Deltagelse på hvis promisser?}

Istanbul er en interessant case, ikke fordi den adskiller sig radikalt fra andre lignende situationer, men fordi nogle iboende konflikter omkring den sociale vending inden for kunsten såvel som byudviklingen støder sammen og dermed bliver særlige synlige. For hvad er det egentlig, der adskiller biennalens intention om gennem performancekunst, diskussioner og seminarer at bruge den skabte offentlighed til at rejse diskussion om byens udvikling fra Occupy Gezis spontane aktioner?

Det er bl.a. forskellen mellem, hvad vi kunne kalde det kulturelt skabte kunstværk og den kulturelle skabelse. Gezi Park blev hurtigt et autonomt og selvgenererende offentligt rum, hvor en mangfoldighed af kulturelle og rumlige udtryk kunne sameksistere. Det er med andre ord ikke samme grad af adskillelse mellem skaberne af værket og modtagerne af værket, hvilket står klart, når man sammenligner de kollektive performances og udtryk under Occupy Gezi med de signerede og intenderede kunstperformances i det offentlige program på biennalen. Hvor biennalen søger et kontrolleret udtryk, opererer Occupy Gezi automatisk med en mangfoldighed og heterogenitet af udtryk.

I det valgte eksempel handler den sociale vending og deltagelsens kunst om, hvem der har retten til byrummet og hvem der tager ejerskab over de offentlighedsdiskurser, der er forbundet med Istanbuls byrum. Istanbuls byrum kan ses som en allerede eksisterende diskurs, hvor kapitaldrevne og statslige interesser på Taksim-pladsen og Gezi Park konfronteres af de urbane aktivister. I sympati med aktivisterne og retten til byen-bevægelsen ønsker kuratorerne Fulya Edemci og Andrea Phillips at inddrage debatten i biennalens offentlige program - med det offentlige rum som den scene, hvorpå performance og diskussioner skal finde sted. Der sker dog en sammenblanding af niveauerne, hvor den aktuelle performance tilsyneladende bliver 'læst' som hyklerisk, fordi det både tages til indtægt for den kuratoriske kritiske rammesætning og biennaleinstitutionens pragmatiske forbindelse til byen og økonomien (uden hvilken, der formentlig ikke var en biennale i Istanbul). Inden for en kunstdiskurs er det meningsfuldt at se på kunsten som relativ autonom eller post-autonom ${ }^{7}$, på én gang selvdefinerende, hvor kunstneren sætter spillereglerne og styrer graden af afgivet kunstnerisk kontrol, men samtidig er afhængig af kunstsystemet som konceptuel forståelsesramme, formidlingsplatform og økonomisk bærende struktur. Selv når kunstneriske og kuratoriske målsætninger - som i casen - nærmer sig byaktivisternes måde at operere på, ser det altså ud til, at der er nogle mærkbare forskelle, som man må prøve at forstå, hvis kunstfeltet ønsker deltagelse fra - og at intervenere i - den urbane offentlighed. 
Andrea Phillips, som var kurator af det offentlige program, responderer retrospektivt på det iboende paradoks i den kuratoriske praksis: at man på én gang har en forestilling om kunsten som værende demokratisk i øjenhøjde med folket, men samtidig opererer med en hierarkisk afsender-modtager struktur og et klassisk kunstbegreb. Samtidig forbinder hun de æstetiske løfter i programmet med en forestilling om frihed gennem deltagelse, men hvor der reelt er tale om det, hun betegner "en neo-liberal privatisering af det sociale og psykologiske":

Privatisering, fordi det offentlige program ikke tillader os at deltage i og forme den transformative proces, men derimod tillader os at blive transformeret. I vores egen frisættelses navn får vi viden overført til os, mens vores rolle som private individer, der træder ind til begivenhederne og kommer ud som den offentlige sfære konstrueret af en den offentlige institution, efterlades intakt. ${ }^{8}$

Phillips' bud er derfor at se på vores forståelse af deltagelse på institutionelt niveau og på forestillingerne om den offentlige sfære som noget givet. Den måde biennalen og kuratorerne italesætter en formodet offentlighed, er således af betydning. For måden at italesætte inkluderer en kompleks sammensætning af den offentlige sfære, af subjekter, affektive kroppe, civilsamfund, brugere, forbrugere, publikum. Måden som offentligheden italesættes på har en væsentlig betydning for karakteren af deltagelse og dermed for karakteren af den offentlighed, der produceres.

Der ligger således en iboende modsætning mellem at ville adressere en deltagende offentlighed i byrummet uden samtidig at udfordre sin egen form som institution. Måden at gå ud i det offentlige rum på må antage en anden form end den institutionelle. Der er med andre ord forskel på at lave kunst inden for institutionens trygge rammer, som primært henvender sig en såkaldt 'kunstoffentlighed' og at iværksætte dem i en stærk politisk, kompleks urban offentlighed som Istanbuls - især når institutionen samtidig sponsoreres af aktører, som den kritiske urbane offentlighed (Occupy Gezi) tager afstand fra. Sammenligner man de interesser og grupper, der engagerede sig i Occupy Gezi i forhold til afsenderne på Istanbul Biennalen, vil kunstinstitutionen virke blasert, konservativ og stivnet i forhold til den levede urbane bevægelse i gaderne. At Istanbul Biennalen samtidig er en del af den globale og kapitaldrevne kunstindustri, der associeres med byens omfattende gentrificeringsprocesser, gør kun det offentlige program mere paradoksal. Kan man som kunstinstitution sympatisere med den urbane bevægelses kritik af den byrumlige gentrificering og manglende inddragelse af Istanbuls borgere, når man samtidig bidrager til selv samme gentrificering og styrkelse af den kapitaldrevne by? Der ligger tydeligvis en modsætning i den måde, hvorpå den urbane offentlighed italesættes fra et institutionelt perspektiv, hvor allerede etablerede kunstnere

8 Phillips, Andrea: upubliceret forelæsning 20I og kuratorer lægger programmet. Den brede og sammensatte offentlighed får med andre ord ikke lov til at deltage i den transformerende proces, der allerede er defineret af kunstinstitutionen og som tillægges kunstens, og i dette tilfælde biennalens, performativitet og sociale agens.

\section{Den autoriserede offentlighed versus den opståede}

At det offentlige program ikke gennemføres som planlagt, men bliver afvist af aktivisterne, der anser biennalen for del af problemet frem for løsningen, peger dog på en produktiv offentlighed, hvis vi ser ud over selve biennalens intention. Biennalens program skabte ikke en deltagende offentlighed som forventet, men i konfrontation med såvel aktivisternes forståelse som de forskellige urbane interesser kom noget alligevel til syne i løbet af processen. Offentlighedsbegrebet kan i den forstand forstås processuelt og tilblivende, som noget der opstår ud over eller forskelligt fra de bagvedliggende intentioner.

Et sådan dynamisk og processuelt offentlighedsbegreb finder vi hos sociologen Brighenti: Han ser, i modsætning til Habermas' offentlighedsbegreb, det offentlige domæne som en "økologi af økologier" (Brighenti 8). Her er f.eks. medieøkologier, urbane økologier og det han kalder opmærksomhedsøkologier, med til at skabe offentligheden. Et sådan begreb om offentlighed hviler derfor på en processuel tilblivelse mellem en lang række forskellige interesser - eller økologier. Ingen af de specifikke økologier kan skabe offentlighed i sig selv, men i konfrontation med andre økologier bliver offentligheden til. Med andre ord er det i konflikten eller friktionen mellem de interessestyrede intentioner, at offentligheden skabes. En $ø$ kologitanke er i den forstand produktiv, når vi ser på Istanbul-casen. For selvom det offentlige program mislykkedes, og dialogen blev afbrudt, blev en række paradokser i deltagelsens kunst synlige i løbet af processen. F.eks. at biennalen med sine private sponsorer selv er en del af den globale kapitalisme, som kuratorerne forsøgte at gøre op med, at formen i måden at italesætte en formodet offentlighed er afgørende for, hvad der kommer ud af processen. Ud fra et strukturelt synspunkt kan intentionen om at inddrage den urbane offentlighed siges at være mislykket. Aktivisternes og kunstnernes perspektiv mødtes ikke, derimod blev den kunstneriske diskurs direkte afbrudt af aktivisternes interventioner. Dog vil man ud fra en økologitanke kunne se på, hvordan de to diskursers sammenstød synliggjorde en grundlæggende egenskab ved deltagelsens kunst, nemlig at det ikke går restløst op $i$ en konsensus om, hvad det offentlige rum indebærer, men snarere er en økologi af konstant tilblivende artikulationer og konfrontationer. Spørgsmålet er, hvordan man medtænker dette aspekt i den kuratoriske proces, og om man kan give kunsten lov til at bevare noget af sin værkkarakter i form af relativ autonomi? 


\section{Konklusion}

Når vi taler om kunstens kapacitet til at inddrage og italesætte den sociale virkelighed, f.eks. i en urban ramme, sættes værkets relative autonomi i spil, dels ved at kunstneren afgiver noget af sin kunstnerisk auteur-mæssige kontrol og dels ved, at værket får en performativ karakter, der udvisker klare grænser mellem værk og omverden. Kunstneren sætter gennem værket (performancen, projektet) en række regler og betingelser, hvilket ikke er ensbetydende med, at der er fuld kontrol, men snarere kræver en vis uafhængighed fra værk/projekt-eksterne kræfter. Samtidig kan den relative autonomi forholde sig stedsspecifikt til konteksten og det sociale rum, eller endog inkludere publikum/offentligheden som deltagere i processen. Dette kan f.eks. gøres gennem en direkte invitation til deltagelse. En sådan invitation til deltagelse kan besvares med ikke-deltagelse eller tilbagetrækning. Ikke at ville deltage kan således også forstås som en form for deltagelse, der f.eks. italesætter værkets præmisser og dets institutionelle ramme. En sådan anti-deltagelse er relevant i forhold til Istanbul Biennalens offentlige program. For selvom kuratoren Erdemcis invitation til den urbane offentlighed om deltagelse blev besvaret med kritik fra aktivisterne, blev institutionens strukturelle begrænsning blotlagt i løbet af konflikten. Grænsen mellem kunsten og de supportstrukturer den indgår i, synes sværere at skelne, når netop det sociale rum bliver en integreret del af kunsten som en iscenesættelse af værk og diskurs. Værket kan med andre ord ikke få lov at fungere som æstetisk manifestation med den åbenhed og tvetydighed dette indebærer, fordi det først og fremmest læses som et politisk udsagn. Det politiske er her den primære drivende kraft hos aktivisterne. Grænsen mellem værk/manifestation- og publikum/social-sammenhæng, som nok er kompleks i en kunstnerisk sammenhæng, er snarere ikkeeksisterende hos aktivisterne. Selvom ikke alle deltager, er der hos aktivisterne en forestilling om alles mulighed for at deltage.

Denne - måske utopiske - forestilling om alles deltagelse genfindes til dels også i den kuratoriske idé med et offentligt program: Her bruges performances og seminarer til at skabe en større oplevelse af deltagelse, både forstået som inddragende men også som kunstens deltagelse i offentligheden og i samfundsmæssige problemstillinger. Som sådan er programmet et supplement til den udstilling, der typisk har en mere indadvendt og eksklusiv position i samfundet. Men følger vi Andrea Phillips' analyse, vil det være væsentligt ikke blot at søge svarene i forskellen mellem kunst og aktivisme, men også i den måde, hvorpå vi typisk forstår forholdet mellem kunst og publikum, dvs. kunstinstitutionens og kuratorenes forsøg på at inddrage publikum. Kunsten har længe (i hvert fald siden Kant) været kendetegnet ved en forestilling om mulig transformation. I det 20. århundredes avantgarder blev kunstens transformerende kraft knyttet både til individet og sociale og samfundsmæssige strukturer. I det 2I. århundrede eksisterer denne forestilling om transformation stadig, men den er først og fremmest blevet en kuratorisk ambition. Det er den kuratoriske rammesætning (æstetisk såvel som diskursiv), som sætter kunsten i spil i samfundet. Men, som Phillips påpeger, er transformation typisk forstået som noget, der ligger uden for kunstinstitutionen selv, og deri, siger hun, ligger dets problem. Publikum indbydes til deltagelse for, at de igennem den æstetiske oplevelse kan lade sig transformere, men er institutionen selv klar til transformation? Og til transformation af en fastlåst idé om, hvad offentlighed er?

Ligeledes bør vi være opmærksomme på, at netop qua forestillingen om en urban offentlighed, der skal forandres med kunsten som middel, kommer kunsten ofte til kort, fordi den urbane offentlighed, som vi har argumenteret for, nærmere må ses som sammensat af de spontane, emergente og uforudsigelige sammenstød, der momentant kan sameksistere, men som aldrig kan etableres som en institutionel eller æstetisk strategi.

\section{LITTERATURLISTE}

Adanali, Yasar. “\#Occupy Gezi. The Park Revolution”. Topos Magazine. The International Review of Landscape Architecture and Urban Design, 2013, 46-5I.

Altay, Can. "Here We Are: The Imagination of Public Space in Gezi Park". Creative Time Reports. Io. August 2014 http://creativetimereports.org/20I3/06/14/here-we-are-the-imagination-of-publicspace-in-gezi-park/

Bishop, Claire. Artifical Hells: Participatory art and the politics of spectatorship. London: Verso, 2012. Bourriaud, Nicolas. Relational Aesthetics. Paris: Presses du reel, 2002.

Brighenti, Andrea Mubi. The Publicness of Public Space: On the Public Domain. Trento: Università di Trento, 20Io.

Groys, Boris. "A Genealogy of Participatory Art". The Art of Participation 1950 to Now. Red. Rudolf Frieling. London: SFMOMA \& Thames \& Hudson, 2008, I8-3I.

Fabian, Louise \& Kristine Samson. "DIY Urban Design: Between ludic tactics and strategic planning". Enterprising Initiatives in the Experience Economy. Red. Britta Timm Knudsen, Dorthe Refslund Christensen og Per Blenker. London: Routledge, 20I4: 38 - 59 .

Ekeberg, Jonas. Red. New Institutionalism. Oslo: OCA, 2003.

Feigenbaum, Anna, Fabian Frenzel \& Patrick McCurdy. Protest Camps. London, New York: Zed Books, 2013.

Francis, M. A. "Dirty work: Art beyond 'Autonomy"'. Journal of Visual Art Practice, 6:I (2007): 33-44 Hardt, Michael \& Antonio Negri. Multitude: War and Democracy in the Age of Empire. New York:

Penguin, 2005.

Harvie, Jen. Fair Play: Art, Performance and Neoliberalism. London: Palgrave Macmillan, 2013. Harvey, David. "The Right to the City." New Left Review 53:I (2003): 939-94I.

Harvey, David. Rebel Cities: From the Right to the City to the Urban Revolution. London: Verso. 2012. Jackson, Shannon. Social Works: Performing art, supporting publics. New York: Routledge $20 I I$.

Jalving, Camilla. Vark som handling: performativitet, kunst og metode. København: Museum Tusculanum Press, 2011. 
Jørgensen, Peter Schultz. "Den foranderlige by - midt i paradigmeskiftet". Red. Jan Bruun Jensen, Christensen, Tina Gørtz \& Ingelise Konrad. Kulturplaner - fra velfardsplanlagning til kulturel byudvikling. København: Bogværket, 2008, 38-47.

Kerstin Bergendal: Park Leg: http://www.parklek.com/Larsen, Lars Bang. Kunst er norm. Aarhus: Det Jyske Kunstakademi, 2009.

Kenneth Balfelt: Genhusning af øldrikkere på Enghave Plads http://kennethbalfelt.org/enghaveplads/enghave-plads-workshop-video/

Larsen, Lars Bang. Kunst er norm. Aarhus: Det Jyske Kunstakademi, 2009.

Lefebvre, Henri. Writings on Cities. Red. Koffman, Eleneore and Elizabeth Lebas. Oxford: Blackwell Publishers, 1986

Lehmann, Hans-Thies. Postdramatisches Theater. Frankfurt: Verlag der Autoren, I999.

Lilliendahl Larsen, Jan. "Vage rum”, "Kreativitet", "midlertidige byrum” og politisk urbanitet". Byen $i$ Bevagelse. Mobilitet, politik, performativitet. Roskilde: Roskilde Universitetsforlag, 20I2, I48-I66.

Möntmann, Nina. Red. Art and its institutions: Current conflicts, critique and collaborations. London: Black Dog Publishing, 2006.

Oswalt, Philipp, Overmeyer, Klaus \& Misselwitz, Philipp. Urban Catalyst: The Power of Temporary Use. Berlin: DOM Publishers, 2013.

Phillips, Andrea. upubliceret konferencebidrag på Art Cought in Crossfire: Conflict and negotiation in contemporary urban spaces, KøS, København 2I.03.20I4

Rancière, Jacques. The Emancipated Spectator. London: Verso, 20II.

Rancière, Jacques. Dissensus: On Politics and Aesthetics. London: Continuum Books, 2010.

Reclaim Istanbul: http://reclaimistanbul.com/

Ross, Andrew No Collar: The Humane Workplace and Its Hidden Costs. Philadelphia: Temple University Press, 2004.

Samson, Kristine. "Den performative by: design, planlægning og oplevelse". Byen i Bevagelse. Mobilitet, politik, performativitet. Roskilde: Roskilde Universitetsforlag, 20I2, 219-242.

Skot-Hansen, Dorte. Byen som scene. Kultur og byplanlagning i oplevelsessamfundet. København: Bibliotekarsamfundet, 2007.

Thompson, Nato "Living as Form". Living as Form. Socially engaged art from I99I-20II. Red. Nato Thompson. New York: Creative Time Books \& MIT Press, 2012, I6-33. 